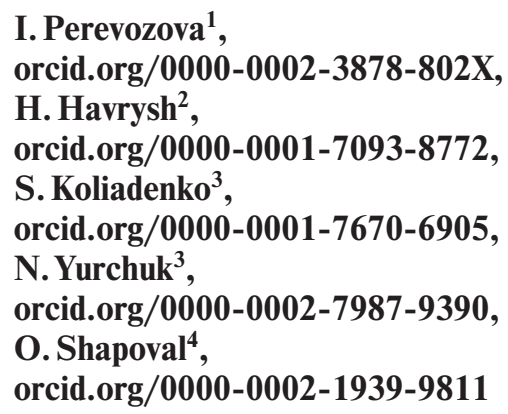

1 - Ivano-Frankivsk National Technical Oil and Gas University, Ivano-Frankivsk, Ukraine, e-mail: perevozova@ukr.net 2 - Robert Elworthy Institute of Economics and Technology, Kropyvnytskyi, Ukraine

3 - Vinnytsia National Agrarian University, Vinnytsia, Ukraine

4 - National Academy of the National Guard of Ukraine, Kharkiv, Ukraine

\title{
ANALYSIS AND FORECAST OF PRODUCTION AND UTILIZATION OF INDUSTRIAL WASTE IN UKRAINE
}

Purpose. To analyze the situation with the generation, utilization and accumulation of industrial wastes, to develop the mathematical model of forecasting and, using this model, to identify the main trends in forming and accumulating waste for next years and current threats.

Methodology. In the scientific research presented in the article, general and special methods of cognition were applied. For the use of the indicated methods complex approach was applied. Complex use of methods of regular supervision, comparative analysis, content analysis, and logical generalization, quantitative and qualitative comparison allowed not only determining the range of industries that make a major contribution to the formation of existing industrial wastes, but also proving that the main polluter is the extractive industry. Complex use of methods of scientific abstraction and mathematical formalization allowed not only creating a mathematical model for the formation of forecasts for industrial wastes for subsequent periods but also strengthening their relevance by highlighting the "colored noise" and predicting trends in the coming years.

Findings. The results of quantitative and qualitative analysis of the annual increase in industrial waste by industries prove the mono-sectoral impact on the formation of the crisis situation. Threats have been detected of multiplicative year-on-year growth of waste accumulated during operation in specially designated places and facilities and annual growth of accumulation of dangerous industrial waste of I-III classes. The created mathematical model allowed carrying out forecasting of volumes of formation and utilization of industrial waste. Due to this, further analytical studies have shown that the volume of waste generation in recent years is twenty times as much as the volumes of disposal. There has also been a catastrophic decrease in the rate of dangerous waste disposal and outpacing the growth of total waste accumulation.

Originality. As a result of the analysis, it is found that the trend of recent years to increase waste generation has been formed due to the extractive industry and quarry development. Threats of a crisis situation formation as a result of the reduction of dangerous waste utilization and the multiplicative year-on-year growth of the total accumulated wastes have been established. During the research, a mathematical model was developed for the analysis of waste generation and utilization and forecasting of their volumes.

Practical value. The results of quantitative and qualitative analysis of the annual increase in the volume of industrial wastes by industries prove the mono-sectoral impact on forming of the crisis situation. The application of the developed mathematical model of forecasting of volumes of waste formation and utilization provides new opportunities for the analysis of the situation and introduction of advanced methods of waste management.

Keywords: industrial waste, extractive industry, mathematical modeling, forecasting, waste management

Introduction. The issue of generation and management of industrial waste in Ukraine is extremely acute. This is evidenced, in particular, by the orders of the Cabinet of Ministers of Ukraine "On Approval of the National Waste Management Plan until 2030", "National Waste Management Strategy for Ukraine" and other regulations. A much more complicated problem is the fact that industrial waste has been accumulating for a long time. For the industrial regions of Ukraine, a characteristic part of the landscape is heaps of mines, slag and ash dumps of metallurgical plants, sludge accumulators and tailings. More than 160 million tons of metallurgical slag alone and $\sim 250$ million tons of slag from thermal power plants have been accumulated.

The situation is aggravated by the fact that the metallurgical industry adds 10-11 million tons of new slag each year, and thermal power plants - another $\sim 6-7$ million tons. In other industries, the volume of industrial waste is also increasing from year to year. Of the total annual waste, a small amount is disposed making only $\sim 12 \%$. According to the types of industrial waste in Ukraine, only $45 \%$ of the volume of produced metallurgical slag is utilized annually, while in developed countries this figure is more than $90 \%$. The situation is even more disappointing for slags from TPPs - only $\sim 7.7 \%$ of them

(C) Perevozova I., Havrysh H., Koliadenko S., Yurchuk N., Shapoval O., 2021 are recycled in Ukraine, while, for comparison, in EU countries $-43 \%$.

This indicates that waste management requires new approaches and tools.

Literature review. The problem of industrial waste management is widely discussed in the domestic scientific literature. Scientists analyze the experience of other countries and suggest ways to solve the problem. Povyakel, et al. [1] analyzes approaches in the field of waste management in Ukraine in connection with the implementation of the EU environmental directives to the legislation of Ukraine. Biletskyi and Cherniak [2] studied the impact of mining technologies on the geological environment. Zhykaliak [3] points to the non-renewability of mineral resources and the need for rational treatment. Fedorchenko and Popov [4] emphasize the need for integrated use of industrial wastes and classifying them as minerals. A detailed analysis of the state of waste management for the industrial regions of Ukraine was provided by Kocheshkova and Trushkina [5]. Petrushenko [6] points to the existence of a conflict of environmental interests in the formation of waste management policy and taxation. The same is indicated in the work by Trehub [7]. Legal aspects of industrial waste management as a deterrent to the transition to a circular economy are considered in the scientific works of Trushkina and Kocheshkova [8], Karnaukh [9] and Bazaluk, et al. [10]. Foreign scientists have also studied the formation and disposal of industrial 
waste. In particular, Stadwell (Studwell, J. (2013). How Asia Works: Success and Failure In the World's Most Dynamic Region) analyzes approaches to industrial waste management in developed Asian countries, Piliaiev [11], Awuchi, et al. [12], Agwaral [13], Sokiran [14], and Caetano [15] provide specific ways to implement effective waste management. Ferronato in [16] considered aspects of waste flow management in developing countries and, in [17], provided a comparative analysis of the benefits and opportunities for "waste valorization". Bilan, et al. [18], Sirait [19] and Nguyen [20] considered not only a theoretical approach but also provided a specific example of industrial waste reduction.

Unsolved aspects of the problem. The above review of scientific papers on industrial waste management can serve as a basis for solving problematic aspects of this issue. However, the scientists have not considered the role of each of the industries in the generation of industrial waste and the creation of a mathematical apparatus for the formation of forecast values of industrial waste generation and disposal in Ukraine, which should be the basis for the overall picture and provide impetus for effective waste management policy.

The purpose of the article is to analyze the situation regarding the generation, utilization and accumulation of industrial waste, to develop a mathematical model of forecasting and, using this model, to identify major trends in the formation and accumulation of waste in the coming years and existing threats.

Methods. The results of scientific research presented in this article were obtained using general and special methods of cognition. An integrated approach was applied to use these methods, which provided a synergistic enhancement to each of them. Comprehensive use of regular monitoring, comparative analysis, content analysis, logical generalization, quantitative and qualitative comparison allowed not only determining the range of industries that make a major contribution to the formation of available industrial waste, but also proving that the main polluter is the extractive industry. The integrated use of methods of scientific abstraction and mathematical formalization allowed not only creating a mathematical model for forecasting the volume of industrial waste for subsequent periods but also strengthening their relevance by highlighting the "colored noise" and predicting trends in the coming years.

Results. The results of complex application of methods of regular observation, comparative analysis, content analysis, logical generalization, quantitative and qualitative comparison. An analysis of the volume of waste generation and disposal for the period according to regular monitoring [21] for the period from 2010-2011 to 2019 was conducted. During this period, with the help of comparative and content analysis, three characteristic intervals were identified. The interval from 20102011 to 2015-2016 has signs of mathematically monotonous waste reduction. The interval from 2015-2016 to 2017 is characterized by certain stabilization at the lowest level for the period under analysis. And the interval from 2017 to this time is characterized by a mathematically monotonous increase in waste.

To objectify the study on the amount of waste generated from economic activity per unit of GDP, the analysis was conducted at constant prices in 2011 at purchasing power parity in units of $\mathrm{kg} / 1000$ dollars USA (Fig. 1) [21]. The reduction in total waste generation in 2013-2014 is due to the problems of war and annexation of territories. This is confirmed by the analysis of changes in annual gross domestic product (GDP) at constant prices in 2011 (Fig. 2) [21] - a decline over the period 2012-2015 and a subsequent increase in 2018 to the level of the year 2009.

This can be explained both by the peculiarities of accounting for the accumulation and disposal of waste by the State Statistics Service, and changes in trends during this period of gross domestic product (GDP) at constant prices in 2011, billion dollars USA (Fig. 2). During the period from 2010 to 2014, there was a decline, and from 2015 to 2018 - GDP

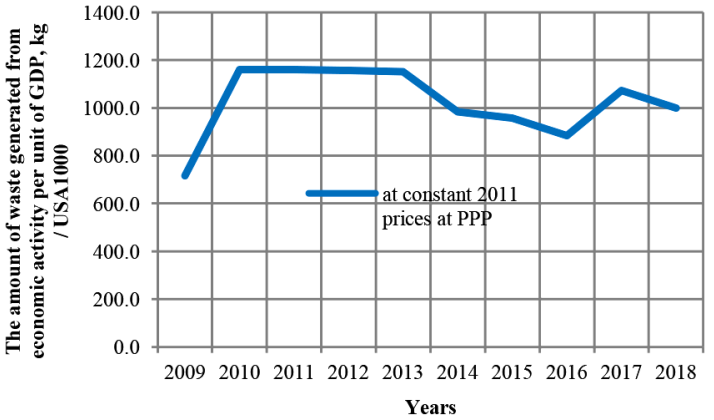

Fig. 1. The amount of waste generated from economic activity per unit of GDP at constant prices in 2011 at purchasing power parity, $\mathrm{kg} / \mathrm{USA} 1000$

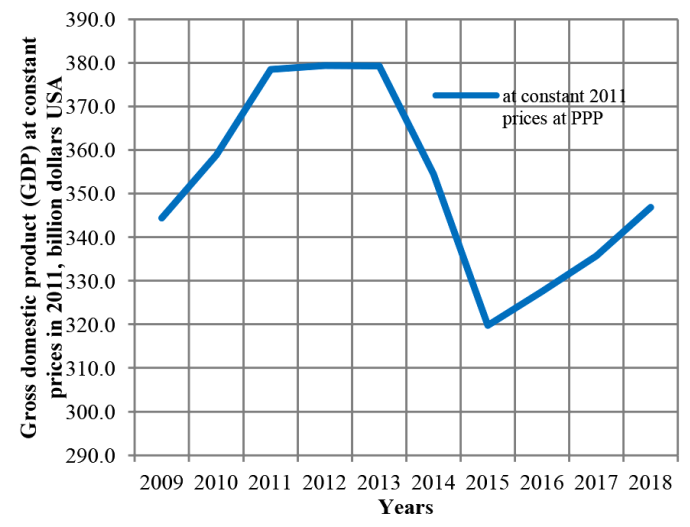

Fig. 2. Gross domestic product (GDP) at constant 2011 prices at purchasing power parity, billion dollars USA

growth (Fig. 2). Characteristic confirmation of this is the analysis of changes in the amount of waste generated from economic activity per unit of GDP at constant prices in 2011 (Fig. 3), according to which the same trends are characteristic of industries that make a major contribution to industrial waste.

The declining trend of total waste generation in 2017-2018 (Fig. 1) can be explained by some reduction (by $3.27 \%$ ) of annual waste and the corresponding adjustment of exchange rates and conversion at purchasing power parity.

Analysis of the volume of waste generated by type of economic activity (Fig. 3) [21] indicates that the main contribution to the formation of total and annual volumes of industrial waste in Ukraine is made by the extractive industry and quarrying (line 2 ), much less - processing industry (line 3 ), even

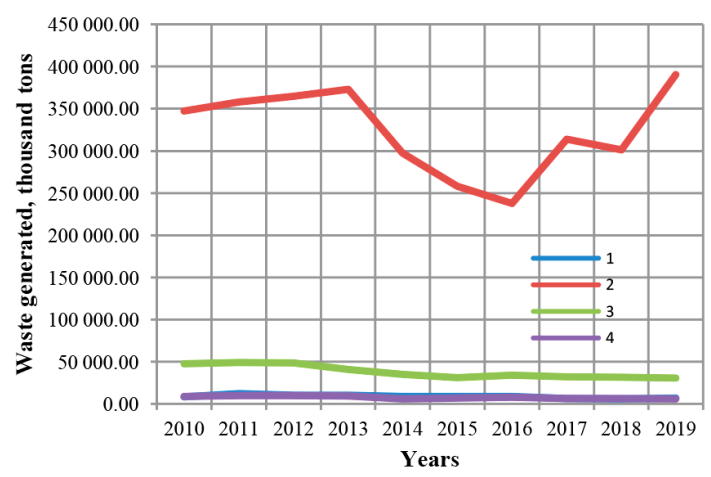

Fig. 3. The amount of waste generated by type of economic activity:

1 - Agriculture, forestry and fishing; 2 - Mining and quarrying; 3 - Manufacturing; 4 - Electricity, gas, steam and air conditioning supply 
less - agriculture, forestry and fisheries (line 1) and supply of electricity, gas, steam and air conditioning (line 4).

The line of generated waste for agriculture, forestry and fisheries and the line of electricity, gas, steam and air conditioning supply in Fig. 3 almost coincide, so for a more specific comparative analysis we give Table [21]. According to the analysis of Table 1, we can see that for 2019 the total construction waste is only $0.0048 \%$ of the waste from the extractive industry and quarrying, and other economic activities in the same year account for only $0.32 \%$ of the total waste.

Thus, it can be argued that in Ukraine, four industries produce the main annual amount of waste. In 2019 again, the total amount of waste from the extractive industry and quarrying; processing industry; agriculture, forestry and fisheries; electricity, gas, steam and air conditioning supply accounts for $98.3 \%$ of the total waste.

The main problem of waste generation and further management lies in one industry only - mining and quarrying. It is this industry that has been forming the trend of significant growth in waste generation since 2018, in contrast to other industries, which indicate a reduction in this indicator (Fig. 3).

It is more detailed to prove this thesis by analysis of industries that generate significant amounts of pollution. During the period from 2015 to 2018, the amount of waste from agriculture, forestry and fisheries decreased annually, respectively, from 8736.8 thousand tons to 5968.1 thousand tons with a slight increase in 2019. The amount of energy waste was reduced from 2016 to 2019 from 7511.5 thousand tons to 5959.2 thousand tons. For industrial production, the reduction of waste occurred from 2011, from 48920.4 thousand tons, to 2019, 30751.8 thousand tons [21]. The mono-sectoral impact on the situation with industrial waste should facilitate the solution of the problem, but the disorder of the legal field in Ukraine, the oligarchic interests of the owners of certain mining and processing industries create a crisis situation in industrial waste management, which is difficult to predict.

Formation of a mathematical apparatus for forecasting waste management activities. To form forecasts for future periods, we used our own modification of the method by G. Box and G. Jenkins. As you know, this technique involves gradual implementation of certain procedures: time series detection; evaluation of parameters; diagnostics of the formed model; prognostication.

These procedures are repeated iteratively, allowing one to achieve the appropriate degree of relevance of the model. To increase the relevance of forecasts, several approaches were used: the time series method - autoregression and the moving (moving) average for certain modification changes. The mathematical model that combines these approaches is called the ARMA $(p, q)$ model. The properties of this model are determined by a combination of AR and MA models, and the stationarity of the variable function of the time series is determined by the AR-part, and the MA-part is formed, respectively, by the so-called "White noise".
Analytically, such a mathematical model can be represented by the equation

$$
y_{\tau}=\sum_{i=1}^{n} a_{i} y_{\tau-p}+\sum_{i=1}^{n}\left(\varepsilon_{\tau}+b_{i} \varepsilon_{\tau-q}\right),
$$

where $p$ is autoregression order; $q$ is the order of the moving (moving) average; $\tau$ is the corresponding time interval, whose order changes discretely and, accordingly, is denoted by the index $i=1,2,3, \ldots, n ; a, b$ are respectively, the coefficients of autoregression and moving (moving) mean, which, in the General case, are represented by matrices of real numbers; $\varepsilon_{\tau}$ is non-random harmonics.

The most effective of the ARMA modifications performed in this study $(p, q)$ models for building effective forecasts was the detection of the so-called "white noise" of non-random harmonics. These harmonics are sometimes called "colored noise". The very selection of the "white noise" of the colored component, which, as it turned out in the calculations, is larger than the components of the "white noise" allowed increasing the relevance of the calculation results. An example of such "colored noise" for forecasting budget financing of environmental areas was the identification of the relationship between budget risks and the allocation of cash flows required for environmental budget items.

The results of the application of the block of methods of mathematical formalization. The use of the proposed mathematical model allows making a comparative analysis of the volume of generation and utilization of industrial waste in Ukraine (Fig. 4).

According to the mathematical model, the polynomial equation is used to predict the volume of industrial waste generation for $2020-2021$

$$
\begin{gathered}
y=-263.71 \cdot x^{4}+7674.5 \cdot x^{3}-69449 \cdot x^{2}+207005 \cdot x^{1}+ \\
+269487 .
\end{gathered}
$$

The equation that describes the volume of utilization of industrial waste for 2020-2021, respectively, is

$$
\begin{aligned}
y=3.7483 \cdot x^{5}- & 215.04 \cdot x^{4}+4031.3 \cdot x^{3}-30395 \cdot x^{2}+ \\
+ & 80372 \cdot x^{1}+89073 .
\end{aligned}
$$

Comparison of the rates of waste generation and utilization for 2020-2021 allows establishing incompatibility between them. The rate of generation is almost an order of magnitude higher than the rate of waste disposal. The tangent of the slope of the trend of waste generation for the period of 2018-2021 is more than ten times greater than the tangent of the slope of the trend of waste disposal for this period (Fig. 4). This indicates the inevitable increase in the total accumulation of industrial waste in the coming years, even with the introduction of immediate measures to increase their utilization. Given the fact that, with such a large difference in trends in the generation and disposal of industrial waste, the probability of a crisis in the presence of waste management practices that have developed over a long historical period is quite signifi-

Characteristics of waste generation by type of economic activity, thousand tons

\begin{tabular}{|l|c|c|c|c|c|}
\hline \multicolumn{1}{|c|}{ Types of economic activity } & 2015 & 2016 & 2017 & 2018 & 2019 \\
\hline Agriculture, forestry and fishing & 8736.8 & 8715.5 & 6188.2 & 5968.1 & 6750.5 \\
\hline Mining and quarrying & 257862.0 & 237461.4 & 313738.2 & 301448.9 & 390563.8 \\
\hline Manufacturing & 31000.5 & 34093.0 & 32176.7 & 31523.2 & 30751.8 \\
\hline Electricity, gas, steam and air conditioning supply & 6597.5 & 7511.5 & 6191.7 & 6322.7 & 5959.2 \\
\hline Construction & 376.2 & 300.2 & 493.8 & 378.8 & 188.7 \\
\hline Other economic activities & 1641.4 & 1442.0 & 1407.4 & 1148.7 & 1405.8 \\
\hline Total waste generation by source & 312268.0 & 295870.1 & 366054.0 & 352333.9 & 441516.5 \\
\hline
\end{tabular}




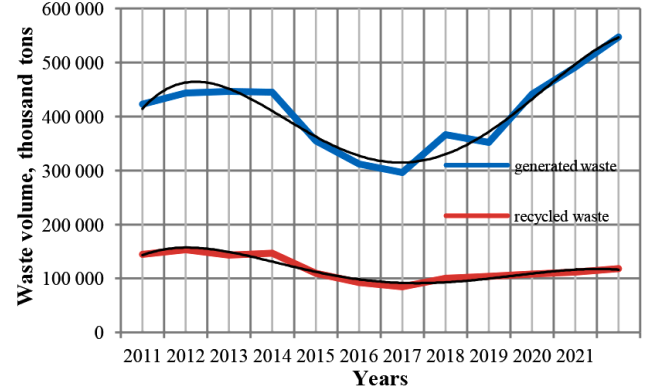

Fig. 4. Forecast of volumes of formation and utilization of industrial waste, thousand tons

cant. The overall picture is significantly deteriorating with the use of comparative data analysis [21] in recent years.

During the period of 2013-2016, there was a significant reduction in the annual generation of waste. While in 2013 this figure was 445262.1 thousand tons, in 2016 this figure was 295870.1 thousand tons. That is, there was a reduction of more than 1.5 times (Fig. 4). At the same time, there was a reduction in waste disposal from 146733.1 thousand tons in 2013 to 84630.3 thousand tons in 2016. That is, the decrease in waste disposal during this period amounted to 1.733 times, which gives $115.6 \%$ compared to the corresponding indicator of waste generation. The results of this application of the method of quantitative and qualitative comparison indicate the incommensurability of annual changes in the volume of generation and disposal of industrial waste. At the same time, despite not very positive changes with the rate of production according to [21], there is a significant rate of waste generation since 2017. The application of the method of quantitative and qualitative comparison with 2019 gives the following results. Volumes of annual waste generation are: in $2017-$ 366054 thousand tons, in 2019 - 441516.5 thousand tons, which is an increase of $21.8 \%$. Volumes of annual waste disposal are: in 2017 - 100056.3 thousand tons, in $2019-$ 108024.1 thousand tons, which is only $7.96 \%$ higher.

That is, for the period of 2017-2019 there is no annual increase in the volume of utilization in accordance with the annual increase in waste generation. The ratio is more than 20.7 times. This is an indicator of a multiplicative increase in the crisis in the field of industrial waste management.

The forecast for the annual volume of waste generation for the period 2020-2021 shows the value, respectively, of 491 454-547 489 thousand tons. Regarding the annual volume of waste disposal for the period of 2020-2021, the forecast data reach 112 050-118 120 thousand tons, respectively. A more significant problem for the deterioration of the environmental situation with consequences for human health is that the volume of recycled waste belonging to hazard classes I-III is reduced from year to year (Fig. 5). Wastes of hazard

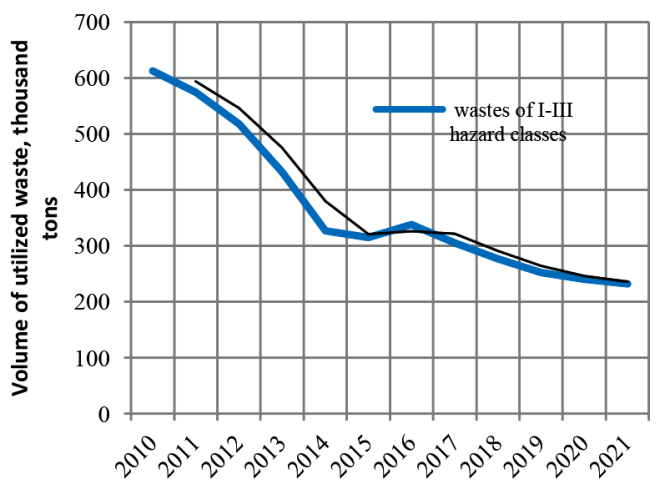

Fig. 5. Forecast of utilization of volumes of industrial waste of I-III classes of danger, thousand tons

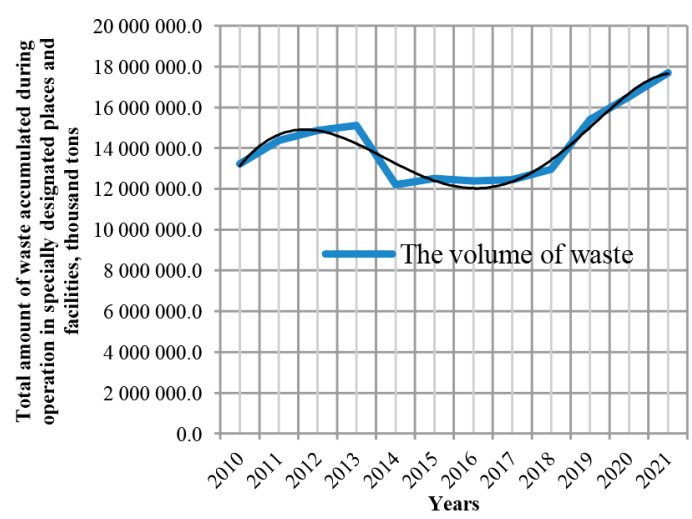

Fig. 6. The total amount of waste accumulated during operation in specially designated places and facilities

classes I-III are also characterized by the presence of three intervals with corresponding trends. More accurate mathematical modeling to establish the trend required the use of filters to increase the relevance of forecasts for 2020-2021.

These changes are extremely negative because they indicate a significant reduction in the volume of hazardous waste disposal. In the time interval from 2010 to 2014 there was a decrease from 612.4 thousand tons to 314.5 thousand tons i. e. by $94.9 \%$. In the time interval from 2017 to 2019 there was a decrease from 305.5 thousand tons to 252.1 thousand tons i. e. 0.82 times. The drive towards the trend decrease is not due to the improvement of the situation, but to the fact that the reduction of the volume of utilized waste of hazard classes IIII has approached a certain limit level. The forecast for the period of 2020-2021 shows the value, respectively, of 204232 thousand tons of recycled waste of I-III hazard classes.

The situation of waste accumulated on the territory of Ukraine during industrial operation in specially designated places and facilities was also studied. Data [21] of regular observation from 2010 to 2019 were selected for analysis and a forecast for 2020-2021 was formed using the developed mathematical model (Fig. 6).

Some decrease in the accumulation of industrial waste since 2014 can be explained by the impact of the exclusion from the statistical circulation of the State Statistics Service of waste accounting data in specially designated places and facilities of the temporarily occupied territories of Donetsk and Luhansk regions. The same data [21] allow us to estimate the amount of accumulated waste in the temporarily occupied Donbas as the difference between the indicators of 2014 and 2013, which also characterizes both the national and regional environmental problem of old industrial areas.

According to the mathematical model $[22,23]$, a polynomial equation is used to predict the total amount of industrial waste accumulated during operation in specially designated places and facilities for 2020-2021

$$
\begin{gathered}
y=-691.47 \cdot x^{5}+14534 \cdot x^{4}-40533 \cdot x^{3}-661934 \cdot x^{2}- \\
-4 \cdot 10^{6} \cdot x^{1}+1.112 \cdot 10^{7} .
\end{gathered}
$$

Some forecast decline in the growth rate of total accumulated industrial waste is explained by the general economic trend. But the total amount of waste already available and the forecast of their significant annual increase outline a disappointing picture of the crisis in industrial waste management in Ukraine.

Conclusions. The results of quantitative and qualitative analysis of the annual increase in industrial waste by industry prove that in Ukraine there are only four industries: mining and quarrying; processing industry; agriculture, forestry and fisheries; supply of electricity, gas, steam and air conditioning, which produce the main annual amount of waste. The contribution, which significantly exceeds the total contribution of all 
other industries, is made by the extractive industry. Monosectoral influence on the situation with industrial waste should facilitate the solution of the problem, but the disorder in the legal field in Ukraine, oligarchic interests, the influence of owners of individual industries create a crisis situation in the management of industrial waste.

The use of the developed mathematical model allowed developing forecasts with the subsequent comparison of volumes of formation and utilization of waste. The analysis of the projected volumes of waste indicates the incommensurability of their generation and utilization, which leads to the deterioration of the crisis with increasing rates.

Complicating the situation is the fact that such industrial waste management has historical longevity. However, the greatest threat is the rate of reduction of utilization of the most environmentally hazardous industrial waste of I-III classes, provided that their volume continues to increase in storage. The application of the developed mathematical model for the analysis of waste generation and utilization and forecasting of their volumes provides new tools for the formation of effective waste management.

\section{References.}

1. Povyakel, L., Snoz, S., Smerdova, L., \& Krivenchuk, V. (2016). New approaches in the field of waste management in Ukraine in connection with the implementation of European Union environmental directives to the national legislation. Ukrainian Journal of Modern Problems of Toxicology, 1, 5-12. 2. Biletskyi, V.S., \& Cherniak, V.M. (2016). The influence of mining technologies on the geological environment. Collection of scientific works of students and teachers, 8, 165-173. Retrieved from http://repository.kpi.kharkov.ua/bitstream/KhPI-Press/43945/1/ZNPSV_2016_8_Biletskyi_Vplyv_ hirnychykh.pdf.

3. Zhykaliak, M.V. (2016). Depletion of effective mineral reserves - a threat to national security of Ukraine. Mineral'ni resursi Ukraïni, 3, 3-7.

4. Fedorchenko, A. O., \& Popov, S. O. (2016). Development of parameters for economic evaluation of the use of waste from the beneficiation of mining enterprises. Technology audit and production reserves, 3/4(29), 47-54.

5. Kocheshkova, I. M., \& Trushkina, N. V. (2017). The state of industrial waste management in the old industrial regions. In: Socioeconomic development of regions: collective monograph, (pp. 61-72). Academic Publishing House of the Agricultural University Plovdiv.

6. Petrushenko, M. M. (2019). Environmental conflicts in the field of waste management: management and taxation. Bulletin of Economic Science of Ukraine, (1), 101-105.

7. Trehub, O.A. (2017). Conflicts and "gray zones" in legal regulation in sphere of waste management. Economics and law, 3, 81-87. https://doi.org/10.15407/econlaw.2017.03.081.

8. Trushkina, N. V., \& Kocheshkova, I. M. (2017). Legal regulation of the development of waste management in Ukraine. Bulletin of Economic Science of Ukraine, 2, 97-102.

9. Karnaukh, O. (2018). Industrial waste as a subject of administrative and legal regulation of domestic and foreign experience. Entrepreneurship, Economy and Law, 6, 168-162.

10. Bazaluk, O., Havrysh, V., Nitsenko, V., Baležentis, T., Streimikiene, D., \& Tarkhanova, E. A. (2020). Assessment of Green Methanol Production Potential and Related Economic and Environmental Benefits: The Case of China. Energies, 13(12), 3113. https://doi.org/10.3390/en13123113.

11. Piliaiev, I. (2019). The Value Dichotomy Curse of Ukraine's Modernization: to Break, or not to Be. Ukrainian Policymaker, 5, 68-76. https://doi.org/10.29202/up/5/8.

12. Awuchi, C.G., Hannington, T., Awuchi, C.G., Igwe, V. S., \& Amagwula, I. O. (2020). Industrial Waste Management, Treatment, and Health Issues: Wastewater, Solid, and Electronic Wastes. European Academic Research, 8(2), 1081-1119.
13. Agarwal, V. (2016). Industrial solid waste: emerging problems, challenges and its solution. International Journal of Management and Applied Science, 2(7), 68-72.

14. Sokiran, M. (2019). Disaster Management, Resilience of System and Space Information Technologies. Advanced Space Law, 3, 120-130. https://doi.org/10.29202/asl/2019/3/10.

15. Caetano, M.D.D.E., Depizzo, D.B., \& Reis, A.O.P. (2017). Analysis of solid waste management and improvement proposal: a case study in carpentry of Cariacica-ES. Gestão \& Produção, 24(2), 382-394. https://doi.org/10.1590/0104530X1413-16.

16. Ferronato, N., \& Torretta, V. (2019). Waste Mismanagement in Developing Countries: A Review of Global Issues. International Journal of Environmental Research and Public Health, 16, 1060. https://doi.org/10.3390/ijerph16061060.

17. Ferronato, N., Rada, E. C., Portillo, M.A. G., Cioca, L. I., Ragazzi, M., \& Torretta, V. (2019). Introduction of the circular economy with in developing regions: A comparative analysis of advantages and opportunities for waste valorization. Journal of Environmental Management, 230, 366-378. https:// doi.org/10.1016/j.jenvman.2018.09.095.

18. Bilan, Y., Nitsenko, V., Ushkarenko, I., Chmut, A., \& Sharapa, O. (2017). Outsourcing in international economic relations. Montenegrin Journal of Economics, 13(3), 175-185. https://doi.org/10.14254/1800-5845/2017.13-3.14.

19. Sirait, M. (2018) Cleaner production options for reducing industrial waste: the case of batik industry in Malang, East Java-Indonesia. The $4^{\text {th }}$ International Seminaron Sustainable Urban Development, IOP Conf. Series: Earth and Environmental Science, 106, 012069. https://doi.org/10.1088/17551315/106/1/012069.

20. Nguyen, N.T. (2020). Marine Culture of Northeast Vietnam: Approaching from the Theory of Culture Ecology. Future Human Image, 13, 66-75. https://doi.org/10.29202/fhi/13/7. 21. State Statistics Service of Ukraine (2020). Economic statistics / Environment. Retrieved from http://www.ukrstat.gov.ua/ operativ/menu/menu u/ns.htm.

22. Andriushchenko, K., Buriachenko, A., Rozhko, O., Lavruk, O., Skok, P., Hlushchenko, Y., Muzychka, Y., ..., \& Kondarevych, V. (2020). Peculiarities of sustainable development of enterprises in the context of digital transformation. Entrepreneurship and sustainability issues, 7(3), 2255-2270. https://doi.org/10.9770/jesi.2020.7.3(53).

23. Mikhno, I., Koval, V., Shvets, G., Garmatiuk, O., \& Tamošiūnienè, R. (2021). Discussion: Green Economy in Sustainable Development and Improvement of Resource Efficiency. Central European Business Review, 10(XX), 1-15. https://doi.org/10.18267/j.cebr.252.

\section{Аналіз і прогноз обсягів утворення та утилізації промислових відходів в Україні}

\section{І. В. Перевозова ${ }^{1}$, Г. О. Гавриш ${ }^{2}$ С. В. Коляденко ${ }^{3}$, Н. П. Юрчук ${ }^{3}$ О. А. Шаповал}

1 - Івано-Франківський національний технічний університет нафти і газу, м. Івано-Франківськ, Україна, e-mail: perevozova@ukr.net

2 - Економіко-технологічний інститут імені Роберта Ельворті, м. Кропивницький, Україна

3 - Вінницький національний аграрний університет, м. Вінниця, Україна

4 - Національна академія Національної гвардії України, м. Харків, Україна

Мета. Проаналізувати ситуацію з утворенням, утилізацією та накопиченням промислових відходів, розробити математичну модель формування прогнозів i, за використання цієї моделі, виявити основні тренди у формуванні й накопичені відходів на наступні роки та наявні загрози. 
Методика. У наукових дослідженнях, представлених у цій статті, були застосовані загальні та спеціальні методи пізнання. Для використання вказаних методів було застосовано комплексний підхід. Комплексне використання методів регулярного спостереження, порівняльного аналізу, контент-аналізу, логічного узагальнення, кількісного та якісного порівняння дозволило не тільки визначити коло галузей, які дають основний внесок у формування наявних обсягів промислових відходів, а й довести, що головним забруднювачем $€$ добувна промисловість. Комплексне використання методів наукового абстрагування й математичної формалізації дозволило не тільки створити математичну модель для формування прогнозів щодо обсягів промислових відходів на наступні періоди, але й посилити їх релевантність виділенням «зафарбованого шуму» та прогнозувати тренди наступних років.

Результати. Результати кількісного та якісного аналізу щорічного нарощування обсягів промислових відходів за галузями доводять моногалузевий вплив на формування кризової ситуації. Виявлені загрози мультиплікативного щорічного зростання обсягів відходів, що накопичені протягом експлуатації у спеціально відведених місцях і об'єктах і щорічного наростання обсягів накопичення небезпечних промислових відходів I-III класів. Створена математична модель дозволила провести прогнозування обсягів утворення та утилізації промислових відходів. Завдяки цьому подальшим аналітичним дослідженням встановлено, що об'єм утворених відходів за останні роки у двадцять разів обсягів утилізації. Також відміченим $є$ катастрофічне зменшення темпів утилізації небезпечних відходів і випереджаюче зростання загальних обсягів накопичення відходів.

Наукова новизна. У результаті проведеного аналізу встановлено, що тренд останніх років на зростання обсягів утворених відходів формується завдяки добувній промисловості та розробленню кар'єрів. Встановлені загрози щодо формування кризового становища в результаті скорочення обсягів утилізації небезпечних відходів і мультиплікаційному щорічному зростанню загального об’єму накопичених відходів. У ході дослідження розроблена математична модель для аналізу утворення та утилізації відходів і прогнозування їх обсягів.

Практична значимість. Результати кількісного та якісного аналізу щорічного нарощування обсягів промислових відходів за галузями доводять моногалузевий вплив на формування кризової ситуації. Застосування розробленої математичної моделі прогнозу об'ємів утворення та утилізації відходів надає нові можливості для аналізу ситуації та впровадження випереджаючих методів поводження з відходами.

Ключові слова: промислові відходи, гірничодобувна промисловість, математичне моделювання, прогнозування, управління відходами

\section{Анализ и прогноз продуцирования и утилизации промышленных отходов в Украине}

\section{И. В. Перевозова ${ }^{1}$, Г.А. Гавриш ${ }^{2}$, С. В. Коляденко ${ }^{3}$, Н. П. Юрчук ${ }^{3}$, Е. А. Шаповал ${ }^{4}$}

1 - Ивано-Франковский национальный технический университет нефти и газа, г. Ивано-Франковск, УкраиHa, e-mail: perevozova@ukr.net

2 - Экономико-технологический институт имени Роберта Эльворти, г. Кропивницкий, Украина

3 - Винницкий национальный аграрный университет, г. Винница, Украина

4 - Национальная академия Национальной гвардии Украины, г. Харьков, Украина
Цель. Проанализировать ситуацию с созданием, утилизацией и накоплением промышленных отходов, разработать математическую модель формирования прогнозов и, применив эту модель, выявить основные тренды в формировании и накоплении отходов на последующие годы, а также имеющиеся угрозы.

Методика. В научных исследованиях, представленных в этой статье, были применены общие и специальные методы познания. Для использования указанных методов было применен комплексный подход. Комплексное использование методов регулярного наблюдения, сравнительного анализа, контент-анализа, логического обобщения, количественного и качественного сравнения позволило не только определить круг отраслей, которые дают основной вклад в формирование имеющихся объемов промышленных отходов, но и доказать, что главным загрязнителем является горнодобывающая промышленность. Комплексное использование методов научного абстрагирования и математической формализации позволило не только создать математическую модель для формирования прогнозов объемов промышленных отходов на следующие периоды, но и усилить их релевантность выделением «окрашенного шума» и прогнозировать тренды последующих лет.

Результаты. Результаты количественного и качественного анализа ежегодного наращивания объемов промышленных отходов по отраслям доказывают моноотраслевое влияние на формирование кризисной ситуации. Обнаружены угрозы мультипликативного ежегодного увеличения объемов отходов, накопленных в течение эксплуатации в специально отведенных местах и объектах и ежегодного нарастания объемов накапливания опасных промышленных отходов I-III классов. Созданная математическая модель позволила провести прогнозирование объемов образования и утилизации промышленных отходов. Благодаря этому дальнейшим аналитическим исследованием установлено, что объем образованных отходов за последние годы в двадцать раз больше объема утилизации. Также отмечено катастрофическое уменьшение темпов утилизации опасных отходов и опережающий рост общих объемов накопления отходов.

Научная новизна. В результате проведенного анализа установлено, что тренд последних лет на увеличение объемов образования отходов формируется благодаря добывающей промышленности и разработке карьеров. Установлены угрозы формирования кризисного положения в результате сокращения объемов утилизации опасных отходов и мультипликационном ежегодном росте общего объема накопленных отходов. В ходе исследования разработана математическая модель для анализа продуцирования и утилизации отходов и прогнозирования их объемов.

Практическая значимость. Результаты количественного и качественного анализа ежегодного наращивания объемов промышленных отходов по отраслям доказывают моноотраслевое влияние на формирование кризисной ситуации. Применение разработанной математической модели прогноза объемов продуцирования и утилизации отходов предоставляет новые возможности для анализа ситуации и внедрения опережающих методов обрашения с отходами.

Ключевые слова: промышленные отходы, горнодобывающая промышленность, математическое моделирование, прогнозирование, управление отходами

Recommended for publication by A.O. Ustenko, Doctor of Economic Sciences. The manuscript was submitted 23.11.20. 